\title{
Reflections on Posthumanism: What does "the economy" have to do with it?
}

Kalpana R. Seshadri

In my graduate seminar on Posthumanism, I discussed the varieties of humanism (British scientific positivism and Continental traditions) in their historical context and their frequently fraught relations with the natural sciences. This background is necessary in order to situate the critique of humanism, i.e. anti-humanism, as a specifically French philosophical formation. I believe that any use of the term posthumanism, which refers to a series of philosophical questions and debates within science studies, should be understood in continuity with the anti-metaphysical program of these earlier critiques. If the metaphysics of presence dominated the critical concerns of these earlier antihumanist theories, what drives posthumanism is primarily a concern with anthropocentrism in all its guises. Furthermore, I found it imperative to clarify that the term "posthuman," which is grammatically and conceptually a substantive, is a technological ideal of what is called trans-humanism-a utopian project that aspires to transcend the frailties of animal embodiment. Most posthumanist theories, on the other hand, argue that any attempt to overcome embodiment would merely perpetuate humanism's notions of perfectibility and human exceptionalism.

By situating posthumanism with reference to the French philosophical tradition we can avoid the temptations of definition and unification that beset almost every scholar writing on the topic. I suggest that we conceptualize posthumanism as a site or even a loosely wound skein of theories and concerns that severally interrogate anthropocentrism. The concerns include climate change and anthropocene ethics, and theories that invariably entangle with science studies, technology, animal studies, vegetal philosophy, speculative realism, object-oriented ontology, new materialisms, and complex systems theories. Thus, instead of asking (once again) what is Posthumanism, I suggest it may be more productive to ask: What can Posthumanisms do?

But first, what has posthumanism(s) neglected to do? As others have also suggested, posthumanism has been precipitate in its interrogation of speciesism and the human-animal-machine ternary at the expense of discussing the history of race and the system of race-ism (dehumanization) in the shaping of the modern human subject. By ignoring race-ism (dehumanization) posthumanism is at risk of appearing either antipolitical or promoting a conservative post-racial politics. In other words, posthumanism has failed to deploy race-ism as a hermeneutical tool to uncover the hidden stakes of claiming human ascendency. The stakes are hidden simply because posthumanist theories have neglected to perceive humanism as anything more than vague ontological belief or ideology. In fact, humanism, however vague or precise, materializes as political economy, and everyday life. Furthermore, the fact that racism has always served as the non-human supplement to humanist political economy has been completely overlooked by posthumanist theories.

In my work on "Posthuman Economics," I propose that race as a non-human supplement serves as a powerful category of analysis-or a valuable perspectival angle-when grappling with climate change as an ethical and political challenge. These various challenges are encapsulated by the terms "Capitalocene" or the "Econocene," 
which succinctly express the responsibility of industrial and financial capitalism built on slavery and colonialism, and its world dominance as the agent of climate change. The specific philosophical intervention that I make pertains not to capitalism as a unitary and totalizing force, but to the concept of "the economy" re-produced and studied by the discipline of Economics as an independent system that works on its own machinic logic. As a methodology, posthumanism differs from Marxist criticism insofar as it repudiates the monolithic unity of Capitalism as an all-encompassing ideology. Rather, it approaches the power of capitalist logic, or more precisely the preponderance of the economic priorities over all aspects of social life, as first and foremost an epistemological problem: namely, the way this logic-i.e. economic common sense-hypostasizes "the economy" as the basis of a modernity that is thoroughly anthropocentric. This economy masquerades as an amoral, non-ideological, even "natural" system with "iron clad laws" that is merely described by politically neutral technocratic economists, who nevertheless dictate policy. By naturalizing "the economy" and economic behavior, economics further consolidates the dominance of its logic as providing solutions to planetary crises.

On the face of it, deconstructing "the economy"-an epistemological concernmay not appear to have much to do with race-ism, climate change, or even posthumanism. It is also not immediately apparent, how or why poking holes into economic epistemology as the common sense of everyday life would illuminate anything about how these issues are related to one another. My argument is that economics and its concept of "the economy" function primarily to obscure and trivialize not only the connections between race, "the economy," and climate change, but renders unthinkable the complexity of what it means to be a citizen of planet earth. Not only is race the non-human supplement of the Capitalocene, obscured by "the economy," it dangerously precipitates a confrontation with earth's general economy of inter-related complex systems-which is a posthumanist reality.

In other words, there is a deep and intrinsic complicity between race thinking, economic logic, and the anthropocene that can only be uncovered by a posthumanism that is committed to epistemological analysis. It is not enough to oppose Capitalism broadly, or inveigh against consumerism, or lament the innumerable effects of climate change. Thus, one of the things that posthumanism can do is prioritize the need for an epistemic shift. The task is not only to expose the epistemological roots of the Capitalocene, its investment in race-ism and its appropriation of "nature," but to promote a politics of resolute anti-race-ism as a corollary to an earth based ethics that respects its complexity. In my view, to be committed to thinking through an anthropocene ethics, means developing a posthumanist discourse that will not shy away from expanding its epistemic horizons, of scaling up its concerns, and seeing the infinitesimal in its greatest detail within the big picture. 